\title{
Yellow colored blooms of Argemone mexicana and Turnera ulmifolia mediated synthesis of silver nanoparticles and study of their antibacterial and antioxidant activity
}

\author{
N. Chandrasekhar ${ }^{1} \cdot$ S. P. Vinay ${ }^{1}$
}

Received: 20 July 2017/ Accepted: 20 October 2017/Published online: 31 October 2017

(C) The Author(s) 2017. This article is an open access publication

\begin{abstract}
In the present work, AgNPs were prepared using a simple bio-reduction method. This is ecologically welcoming and cost-effective method. Yellow colored blooms concentrate of Argemone mexicana and Turnera ulmifolia are used as bio reducing agents in the study. The formation of silver nanoparticles was confirmed by UV-Vis spectrophotometer and characterization of the nanoparticles was done by FTIR, SEM, XRD and EDX. The Antibacterial action of silver nanoparticles was tested against Staphylococus aureus, Pseudomonas aeruginosa, Escherichia coli and Klebsiella aerogenes. The phytochemical analysis of the blooms concentrate has shown the existence of saponins, alkaloids, amino acids, phenols, tannins, terpenoids, flavonoids and cardiac glycosides. In vitro anti-oxidant action of both A. mexicana and T. ulmifolia AgNPs were studied by DPPH assay and reducing power assay.
\end{abstract}

Keywords Phytochemical assay $\cdot$ Argemone mexicana . Turnera ulmifolia · Blooms concentrate · DPPH assay · Reducing power assay

\section{Introduction}

Nanoparticles are generally considered as the particles of 1-100 nm in at least one dimension (Chen et al. 2013; Mohamed and Xing 2012; Tian et al. 2013; Xing et al. 2010). As the size of the particles decreases, the surface

N. Chandrasekhar

chandruharshu@gmail.com

1 Research and Development Center, Department of Chemistry, Shridevi Institute of Engineering and Technology, Sira Road, Tumakuru 572106, Karnataka, India area to volume ratio of nanoparticles increases considerably, this leads to trivial changes in their physicochemical and biological properties. AgNPs have been among the fewest commonly used in our health care system for hundreds of years. In recent times, the nanoparticles have become a passionate awareness in biomedical applications as they possess antifungal, anti-inflammatory, antiviral, and antibacterial actions (El-Badawy et al. 2010; Zhong et al. 2010). AgNPs have been extensively used for diagnosis treatment (Uchihara 2007; Sibbald et al. 2007), coating on medical devices (Galiano et al. 2008), drug delivery (Skirtach et al. 2006), in wound dressing of (Moore 2006), contraceptive devices (Chen and Schluesener 2008) and medical textiles (Vigneshwaran et al. 2007). Nanoparticles can be easily produced by various approaches which include chemical (Sun et al. 2002), electrochemical (Yin et al. 2003), radiation (Dimitrijevic et al. 2001), photochemical and biological techniques (Naik et al. 2002). The majority of chemical reduction procedures applied for the production of NPs involve the use of lethal, dangerous chemicals that causes biological risks and these methods are not ecologically friendly. This leads to emergent requirement for developing eco-friendly methods by bioreduction approaches using plants and microorganisms. The production of nanoparticles using plants materials and their concentrate are more advantageous than the microorganisms as they involve complex procedures of maintaining microbial cultures (Sastry et al. 2003a; 2003b).

Among the different biological methods of silver nanoparticles production, the production of nanoparticles using microorganisms is not much appropriate for industrial practicability because of high sterile conditions \& their care. Hence utilization of plants concentrate is advantageous over microbes (Kalishwaralal et al. 2010). Plantmediated synthesis of nanoparticles provides bio available 
capping agents for the stabilization of AgNPs and also contains important bioreduction agents like citric acid, flavonoids, reductases, ascorbic acids, extracellular electron shuttles, dehydrogenases which show a crucial role in bio-reduction of metal ions into nanoparticles (Pandey et al. 2012).

In the present work, we investigated the simple, effective, low-cost biosynthesis of stable AgNPs by the bioreduction method using aqueous blooms concentrate of $A$. mexicana and T. ulmifolia.

Argemone mexicana, which is usually known as Mexican prickly poppy (List 2007) \& Flowering thistle is found in many parts of India. It is a medicinal plant used in Siddha medicine. The plant has medicinal properties such as purgative, diuretic, and destroys worms. It is used to cure lepsory, skin-diseases, inflammations and bilious fevers. Roots are anthelmintic. Juice is used to cure ophthalmia and opacity of cornea. Seeds are purgative and sedative. The seeds are also taken as a laxative (Moore 1990). The whole plant is used for the treatment of uncomplicated malaria (Willco et al. 2011; Borrell 2014).

Turnera ulmifolia is native to the West Indies and Mexico. It occurs on all island groups in the Bahamian Archipelago as well as Florida, the entire Caribbean region, India, Srilanka, and almost all tropical and subtropical regions throughout the entire world. The plant has medicinal uses such as to treat constipation, diarrhea, cold, flu, and circulatory problems. The laboratory evidence proposes that $T$. ulmifolia concentrate may increase action of antibiotics in aid of methicillin resistant S. aureus (Coutinho et al. 2009).

\section{Experimental}

\section{Materials}

Argemone mexicana plant blooms (Fig. 1) were collected from Devarayanadurga forest, in Tumakuru district, Karnataka, India during the month of May 2017 and T. ulmifolia plant blooms (Fig. 2) were collected from Namachilume near Devarayanadurga forest, in Tumakuru district, Karnataka, India during the month of May 2017. Lyophilised bacterial cultures of $S$. aureus, K. aerogenes, $P$. aeruginosa and E. coli were collected from department

Fig. 1 Argemone mexicana

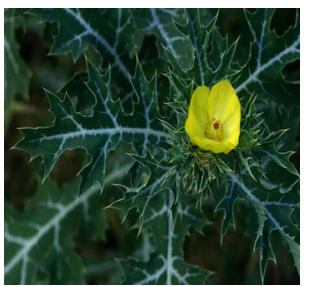

Fig. 2 Turnera Ulmifolia

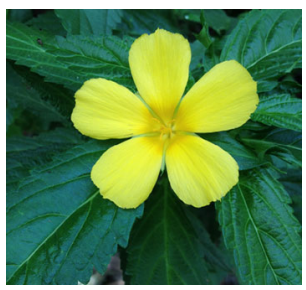

of microbiology, Shridevi Institute of Medical Sciences and Research Hospital, Tumakuru, Karnataka, India. The N.B media was procured by Hi-Media Laboratories. $\mathrm{AgNO}_{3}, \mathrm{KCl}$ and TLC Silica gel $60 \mathrm{~F}_{254}$ plates were procured from Merck Pvt. Ltd. Mumbai, India.

\section{Methods}

\section{Preparation of blooms concentrate}

For the biosynthesis of AgNPs, the collected blooms of Argemone mexicana and Turnera ulmifolia were washed thoroughly with tap water to remove the dust and dirt particles and then washed with double distilled water. $20 \mathrm{~g}$ of each chopped blooms were added to two separate conical flasks containing $100 \mathrm{ml}$ of double distilled water and stirred at $60{ }^{\circ} \mathrm{C}$ for $20 \mathrm{~min}$ on heating mantle. Then, the mixture was cooled for $15 \mathrm{~min}$ and the filtrate is separated using Whatman filter paper No. 1. The collected blooms concentrate (golden yellow color) was used for the biosynthesis of AgNPs.

\section{Synthesis of silver nanoparticles using blooms extracts}

$10 \mathrm{ml}$ of blooms A. mexicana and $10 \mathrm{ml}$ of blooms $T$. ulmifolia were added separately to the $90 \mathrm{ml}$ of $5 \mathrm{mM}$ $\mathrm{AgNO}_{3}$ solution at ambient temperature and stirred continuously for $20 \mathrm{~min}$ using magnetic stirrer. The mixture is allowed for $24 \mathrm{~h}$ for bioreduction process. After $24 \mathrm{~h}$ golden yellow color of the mixture turned to dark brown color due to the formation of AgNPs (Fig. 3a and b). The scheme for the synthesis of AgNPs is given in Fig. 4. The AgNPs obtained from the solution was refined by continual centrifugation at 10,000 rotations per minute for $15 \mathrm{~min}$ using Remi cooling centrifuge C-24 (Karuppiah and Rajmohan 2013). The obtained residual portion (AgNPs) was cleaned using distilled water then dried and stored for further analysis.

\section{Characterization of Ag nanoparticles}

Phytochemical assay Blooms extracts of Argemone mexicana and Turnera ulmifolia were assessed using standard procedures (Sofowora 1993; Trease and Evans 1989; Siddiqui and Ali 1997; Chandrappa et al. 2013; 


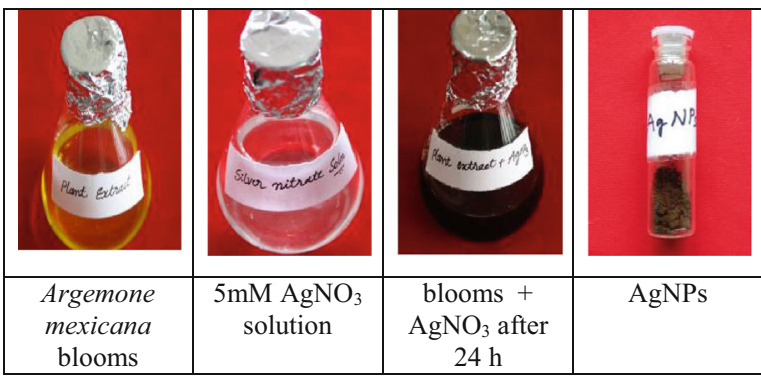

(a)

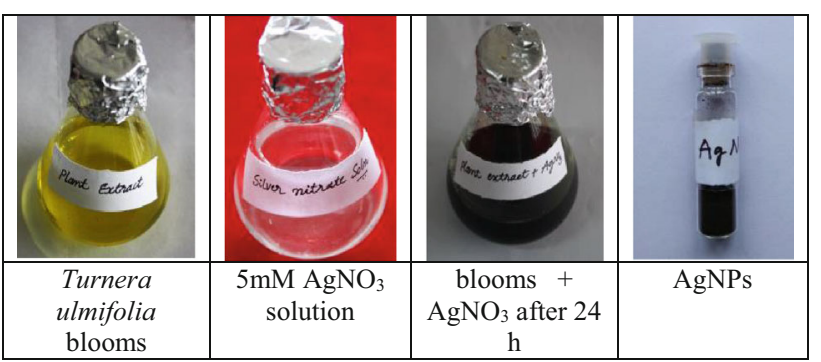

(b)

Fig. 3 a AgNPs produced from Argemone mexicana. b AgNPs produced from Turnera ulmifolia

Ugochukwu et al. 2013) for the presence of phytochemical constituents such as alkaloids, flavonoids, tannins, saponins, terpenoid, phenols, cardiac glycosides, anthraquinones, amino acids and oxalates.

Thin layer chromatography Chromatography is a wellknown method for separation, analysis and identification of extracted compounds to their easy forms. The phytochemical constituents of plants blooms concentrate was carried out using thin layer chromatographic method. TLC was carried out on readily available silica gel plates. Thin layer chromatography plate was kept in hot air oven at $115^{\circ} \mathrm{C}$ for $25 \mathrm{~min}$ for activation. Plants blooms concentrate was applied as spots of $5 \mathrm{~mm}$. The TLC glass chamber was kept for pre-saturation with the mobile phase Ethyl acetate:Toluene:Methanol (0.5:4:0.5) for $30 \mathrm{~min}$. The developed chromatogram was visualized under Ultra Violet light (Wagner and Blodt 1996).
$U V$-visible assay The formation of AgNPs was noted by UV-visible spectrum (model Shimadzu UV) for its maximum absorbance v/s wavelength to confirm the formation of AgNPs.

Fourier transform infra-red spectroscopy (FT-IR) analysis AgNPs were mixed with potassium chloride and a thin AgNPs particles disc was prepared and placed in FTIR for the assay of the AgNPs. The FTIR measurement of sample was recorded in the range of $400-4000 \mathrm{~cm}^{-1}$ using Nicolet Avatar model. It gives information about the rotation and vibration modes which are used to determine the distinct functional groups present in the sample.

$X$-Ray diffraction analysis The reduced AgNPs powder was coated on a glass substrate and the X-ray diffraction measurement were carried out using a powder X-ray instrument (model PAN analytical BV) operating at $40 \mathrm{kV}$ and $30 \mathrm{~mA}$ current. The output was recorded in the form of a graph with $2 \theta$ on $x$-axis and intensity on $y$-axis. The average particle size was calculated using the DebyeScherrer formula

$\mathrm{D}=\mathrm{k} \lambda / \beta \cos \theta$

where $\lambda$ is wavelength, $D$ is particle diameter size, $\beta$ is the full width half maximum, $k$ is a constant (value 0.9) and $\theta$ is Braggs diffraction angle.

Scanning electron microscopy (SEM) assay The particle size and their morphological distribution of the AgNPs were assessed with scanning electron microscopy (SEM). A drop of aqueous solution containing purified silver nanoparticles obtained after repetitive centrifugation was placed on the carbon-coated copper grids and dried under infrared lamp for characterization using TESCAN, VEGA3 LMU model scanning electron microscope at accelerating voltage of $30 \mathrm{kV}$.

Energy dispersive X-ray assay Energy dispersive X-ray is used for the elemental assay or chemical characterization of a sample. It relies on interaction of X-ray excitation and the sample. EDX assay was employed to affirm the

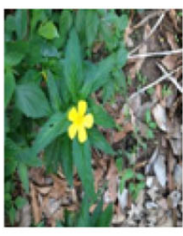

Plant

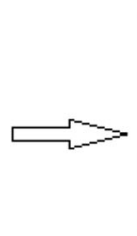

Plant extract

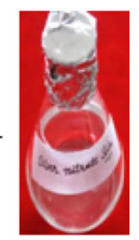

Silver nitrate solution

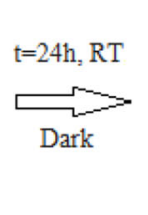

Reaction Mixture

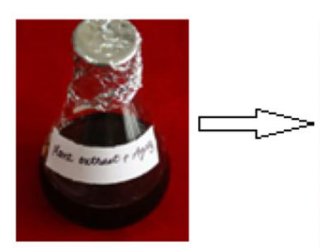

Powder form of AgNPs

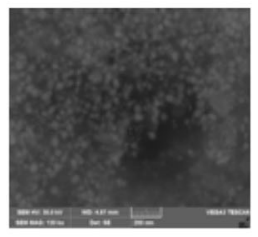

SEM image of AgNPs

Fig. 4 Reaction mechanism 
presence of $\mathrm{Ag}$ in sample and also to find the other elementary compositions in sample.

Antibacterial activity of silver nanoparticles The antibacterial activity of AgNPs produced by A. mexicana and T. ulmifolia blooms concentrate was evaluated by the disc diffusion method for their potential bio-medical applications (Murali Krishna et al. 2016). Staphylococus aureus, $K$. aerogenes, $P$. aeruginosa and $E$. coli bacterial strains were developed in nutrient broth (NB) media for $24 \mathrm{~h}$ at $37^{\circ} \mathrm{c}$ and $1 \mathrm{ml}$ of each broth culture was spread on nutrient agar media plates. 5-mm sterilized filter paper discs were dipped in synthesized silver nanoparticles suspension $(10 \mu \mathrm{l})$ and placed over the discs, double distilled water as negative control, Taxim $\left(1 \mu \mathrm{g} \mathrm{ml}^{-1}\right)$ as standard also used as a positive control and blooms concentrate was placed over the agar plates and incubated for $24 \mathrm{~h}$ at ambient temperature. Zone of inhibition was observed around the disc and was measured (Murali Krishna et al. 2016).

Antioxidant assays The antioxidant activities of synthesized silver nanoparticles were carried out by utilizing DPPH and reducing power assay.

\section{DPPH-free radical scavenging assay}

DPPH $(0.3 \mathrm{mM})$ reagent was prepared in methanol, the synthesized AgNPs sample with various concentration were taken and $300 \mu \mathrm{l}$ of DPPH reagent was added and made it to $3 \mathrm{ml}$. Resulted solution was kept in dark place for $30 \mathrm{~min}$ and measured the absorbance at $517 \mathrm{~nm}$ including negative control. Ascorbic acid was used as standard. Scavenging activity was calculated by the following equation (Patel and Patel 2010).

$$
\begin{aligned}
\text { DPPH searched }(\%)= & {[(\text { A control }- \text { A test })} \\
& \div \text { A control }] \times 100
\end{aligned}
$$

\section{Reducing power assay}

Various concentrations of test samples were prepared with $0.75 \mathrm{ml}$ of Potassium ferricyanide and $0.75 \mathrm{ml}$ of Phosphate buffer, this mixture was incubated at $50{ }^{\circ} \mathrm{C}$ for $20 \mathrm{~min}$, to this $0.75 \mathrm{ml}$ of Tri-chloro acetic acid was added and centrifuged at 3000 rotation/min for $10 \mathrm{~min}$. Finally, the supernatant was mixed with equal volume of double distilled water and $0.1 \mathrm{ml} \mathrm{FeCl}_{3}$. The absorbance was recorded at $700 \mathrm{~nm}$.

\section{Results and discussion}

\section{Phytochemical analysis}

The results of phytochemical screening of A. mexicana and T. ulmifolia blooms showed the presence of flavonoids, saponins, alkaloids, amino acids, phenols, tannins, terpenoids and cardiac glycosides (Table 1).

\section{TLC}

The thin layer chromatographic study of $A$. mexicana and T. ulmifolia blooms concentrate have shown distinguishable different bands of phytochemicals (Figure 5).

\section{UV-Vis-spectroscopy analysis}

Bio-reduction of $\mathrm{Ag}^{+}$ions present in the solution of $\mathrm{AgNO}_{3}$ into silver nanoparticles by the phytocompounds present in the A. mexicana and T. ulmifolia plants blooms concentrate was studied using UV-visible spectroscopy.

Table 1 Phytochemical analysis (blooms extracts)

\begin{tabular}{llll}
\hline S. No. & Phytochemicals & Argemone mexicana & Turnera ulmifolia \\
\hline 1 & Flavonoids & ++ & ++ \\
2 & Alkaloids & +++ & +++ \\
3 & Phenols & ++ & + \\
4 & Tannins & + & + \\
5 & Cardiac glycosides & ++ & + \\
6 & Saponins & + & +++ \\
7 & Anthraquinones & - & - \\
8 & Amino acids & + & + \\
9 & Oxalate & - & - \\
10 & Terpenoids & ++ & ++ \\
\hline
\end{tabular}

+ , confirms; -, absent

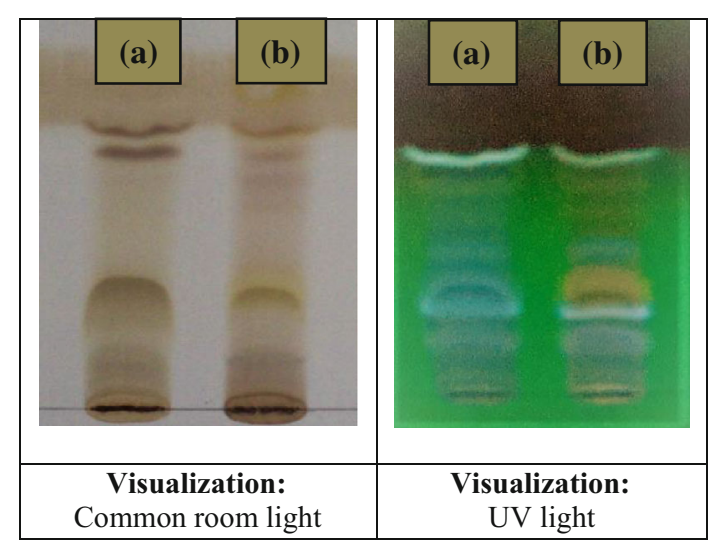

Fig. 5 TLC of blooms extracts. a Argemone mexicana blooms extract, b Turnera ulmifolia blooms extract 
Fig. 6 UV-vis spectrum of AgNPs synthesized by blooms concentrate. a Argemone mexicana AgNPs. b Turnera ulmifolia AgNPs

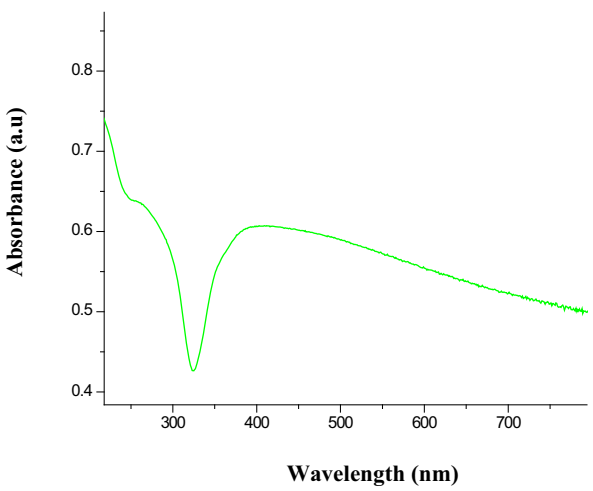

(a)

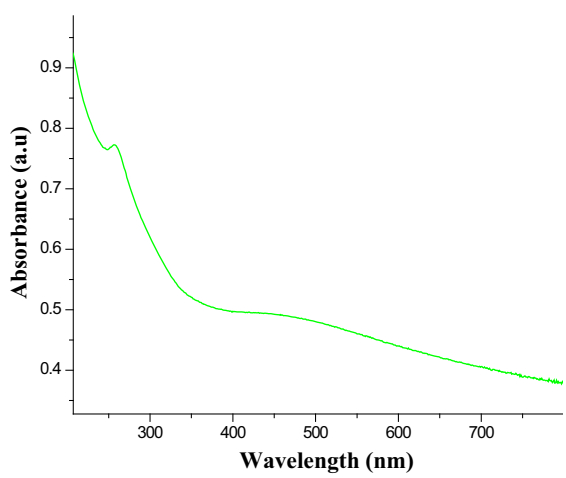

(b)
UV-visible spectrograph of AgNPs solution was noted as a function of time by a quartz cuvette and water as reference. Highest absorbance peak was observed at $398 \mathrm{~nm}$ for $A$. mexicana Fig. 6a (Karthika et al. 2014) and $423 \mathrm{~nm}$ for $T$. ulmifolia Fig. 6b (Arora and Grewal 2015), which indicates the formation of AgNPs.

\section{Fourier transform infra-red spectroscopy (FT-IR) analysis}

FT-IR (Fourier transform infra-red spectroscopy) spectrum was performed to identify and assigned to determine the different functional groups present in the synthesized AgNPs by A. mexicana and T. ulmifolia blooms extracts (Fig. 7a, b). The IR bands were observed at 3790, 3436, 2920, 2350, 1593, 1385, 1264, 675 and $527 \mathrm{~cm}^{-1}$ was determined in the AgNPs formed by A. mexicana blooms extracts (Fig. 7a). The strong bands which appeared at $3790 \mathrm{~cm}^{-1}$ Alcohol O-H stretching and $3436 \mathrm{~cm}^{-1}$ Primary amine $\mathrm{N}-\mathrm{H}$, the bands at $2920 \mathrm{~cm}^{-1}$ Alkane $\mathrm{C}-\mathrm{H}$, $2350 \mathrm{~cm}^{-1}$ Carbon dioxide $\mathrm{O}=\mathrm{C}=\mathrm{O}, 1593 \mathrm{~cm}^{-1}$ Cyclic alkene $\mathrm{C}=\mathrm{C}, 1385 \mathrm{~cm}^{-1}$ Sulfate $\mathrm{S}=\mathrm{O}, 1264 \mathrm{~cm}^{-1}$ Aromatic ester $\mathrm{C}-\mathrm{O}, 675 \mathrm{~cm}^{-1}$ Halo compound $\mathrm{C}-\mathrm{Br}$ and the low band at $527 \mathrm{~cm}^{-1}$ corresponds to Halo compound C-I, while IR bands were observed at 3783, 3439, 2924, 2849, $1593,1381,1258,681$ and $536 \mathrm{~cm}^{-1}$ was noticed in AgNPs formed by Turnera ulmifolia blooms extracts (Fig. 7b). The strong bands which appeared at $3783 \mathrm{~cm}^{-1}$ Alcohol O-H stretching and $3439 \mathrm{~cm}^{-1}$ Primary amine N$\mathrm{H}$, the bands at $2924 \mathrm{~cm}^{-1}$ Alkane $\mathrm{C}-\mathrm{H}, 2849 \mathrm{~cm}^{-1}$ weak band at Alcohol O-H, $1593 \mathrm{~cm}^{-1}$ strong band at Cyclic alkene $\mathrm{C}=\mathrm{C}, 1381 \mathrm{~cm}^{-1}$ Sulfate $\mathrm{S}=\mathrm{O}, 1258 \mathrm{~cm}^{-1}$ Aromatic ester $\mathrm{C}-\mathrm{O}, 681 \mathrm{~cm}^{-1}$ Halo compound $\mathrm{C}-\mathrm{Br}$ and the low band at $536 \mathrm{~cm}^{-1}$ corresponds to Halo compound C-I. The FT-IR spectra of the AgNPs and also by the phytochemical analysis of the blooms concentrate, indicates the existence of phytochemicals such as presence of flavonoids, saponins, alkaloids, amino acids, phenols, tannins, terpenoids and cardiac glycosides, which might have played an active in the process of bio synthesis of silver nanoparticles (Karuppiah and Rajmohan 2013; Sathyavathi et al. 2010; Daizy 2011).

\section{$X$-ray diffraction analysis}

X-ray diffraction pattern was recorded for the synthesized AgNPs are shown in Fig. 8a, b, which shows a number of
Fig. 7 IR spectra of AgNPs synthesized using blooms concentrate. a Argemone mexicana AgNPs, b Turnera ulmifolia AgNPs

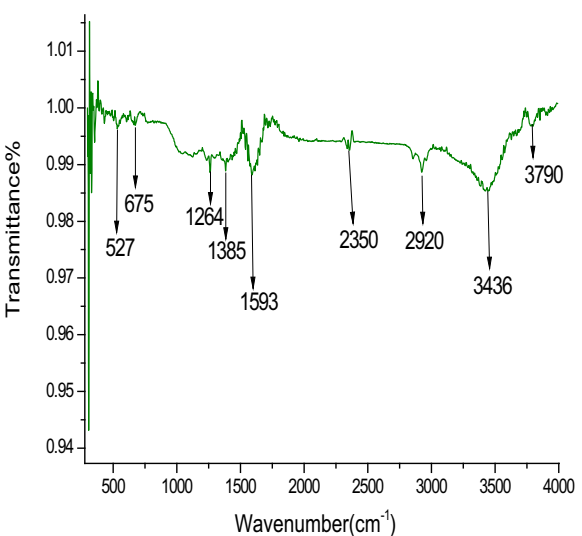

(a)

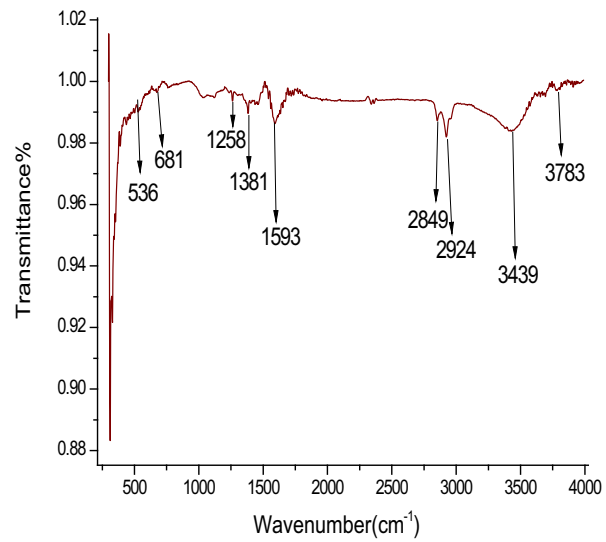

(b) 


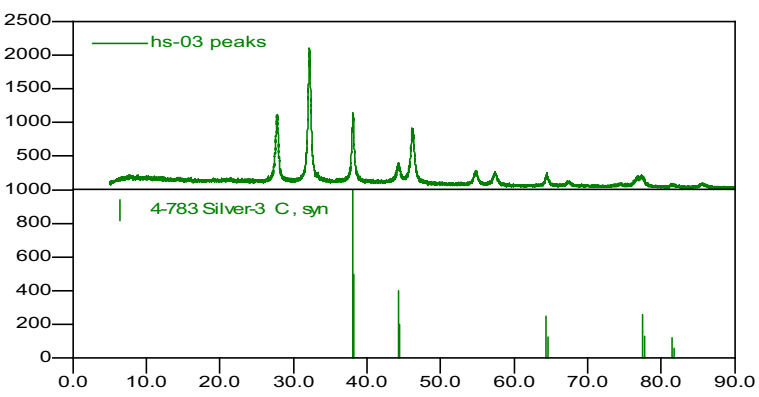

(a)

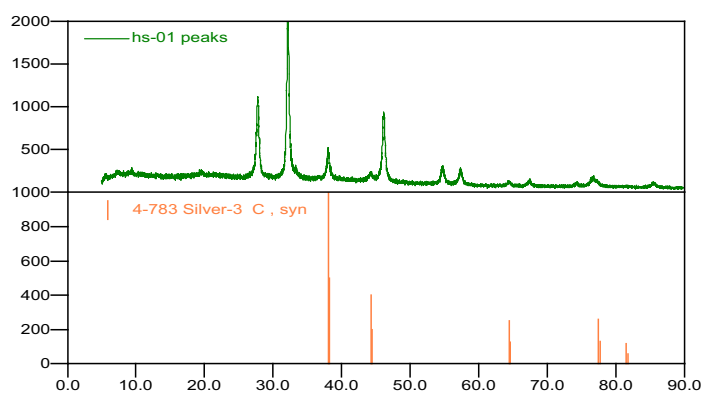

(b)

Fig. 8 XRD patterns recorded for the AgNPs synthesized using blooms concentrate. a Argemone mexicana AgNPs. b Turnera ulmifolia AgNPs

Bragg reflections corresponding to (111), (200), (220) and (311) sets of lattice planes are observed. Which may be indexed based on the structure of Ag. The diffraction peaks at $2 \theta=38^{\circ}, 44^{\circ}, 64^{\circ}$ and $77^{\circ}$ were indexed with the planes (111), (200), (220) and (311) for the fcc lattice of obtained silver (Ag) as per the Joint Committee on Powder Diffraction Standards (JCPDS) Card No. 04-783 was matched with database. XRD has revealed the average size (D) of synthesized AgNPs was found to be $29.13 \mathrm{~nm}$ for $A$. mexicana AgNPs and $31.47 \mathrm{~nm}$ for T. ulmifolia as calculated using Debye-Scherer formula. The XRD pattern thus clearly shows that the synthesized AgNPs are crystalline in nature (Agrawal and Kulkarni 2017).

\section{Scanning electron microscopy analysis}

The SEM has shown the uniform distribution of AgNPs. The SEM images (Fig. 9a, b) has shown separate AgNPs as well as particle agglomeration. This indicates that the particle size is spherical shape with an average size of $29.34 \mathrm{~nm}$ for A. mexicana AgNPs and $32.42 \mathrm{~nm}$ for $T$. ulmifolia AgNPs. Both the particles have the particle size ranging from 23 to $38 \mathrm{~nm}$, respectively (Abdelghany et al. 2017).

Fig. 9 SEM images for the AgNPs synthesized using blooms concentrate.

a Argemone mexicana AgNPs, b Turnera ulmifolia AgNPs

\section{EDX analysis}

The EDX spectrum describes elemental analysis of the AgNPs. The spectra shows characteristics of $\mathrm{Ag}$ signals was obtained at the energy of $3 \mathrm{keV}$, for silver (Ag), and also some of the weak peaks for $\mathrm{C}, \mathrm{Cl}, \mathrm{O}, \mathrm{N}$ and $\mathrm{Cl}$ were found in (Fig. 10a, b). The emission energy at $3 \mathrm{keV}$ indicates the reduction of silver ions to elemental of silver.

\section{Antibacterial assay}

The synthesized AgNPs by the blooms concentrate of $A$. mexicana and T. ulmifolia have a significant antibacterial activity against $K$. aerogenes followed by $P$. aeruginosa, E. coli, and $S$. aureus were tested by disc diffusion method. The zone of inhibition was found to be in the range of 20-24 mm for A. Mexicana (Fig. 11; Table 2) and $21 \mathrm{~mm}-$ $27 \mathrm{~mm}$ for T. ulmifolia (Fig. 12; Table 3). Maximum antibacterial activity was shown by $T$. ulmifolia AgNPs with inhibition zone maximum of $27 \mathrm{~mm}$ than A. mexicana (Murali Krishna et al. 2016). Based on the zone of inhibition results, it is evident that the AgNPs have potential antibacterial activity.

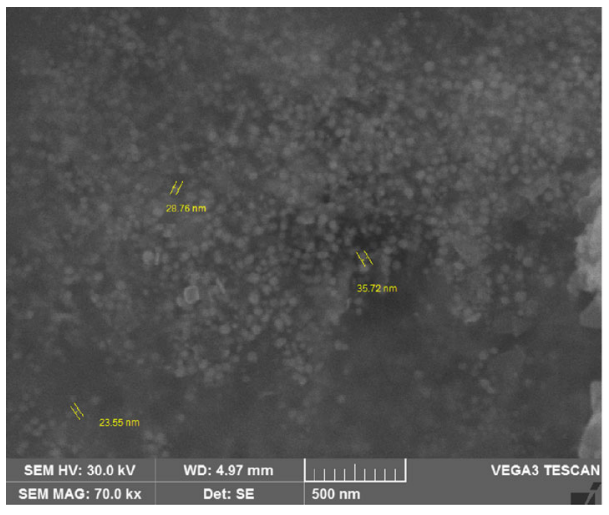

(a)

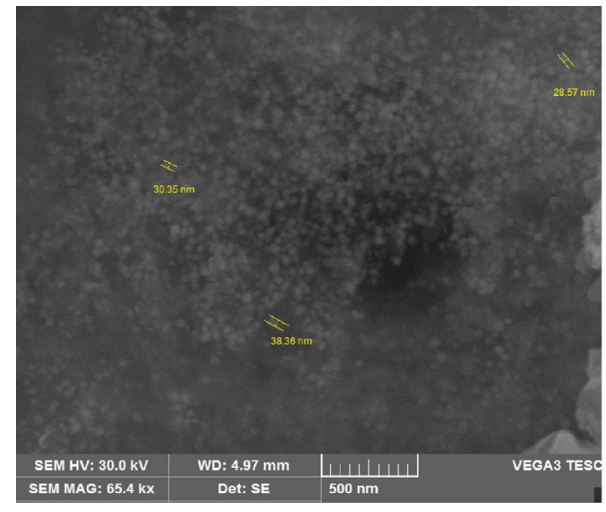

(b) 


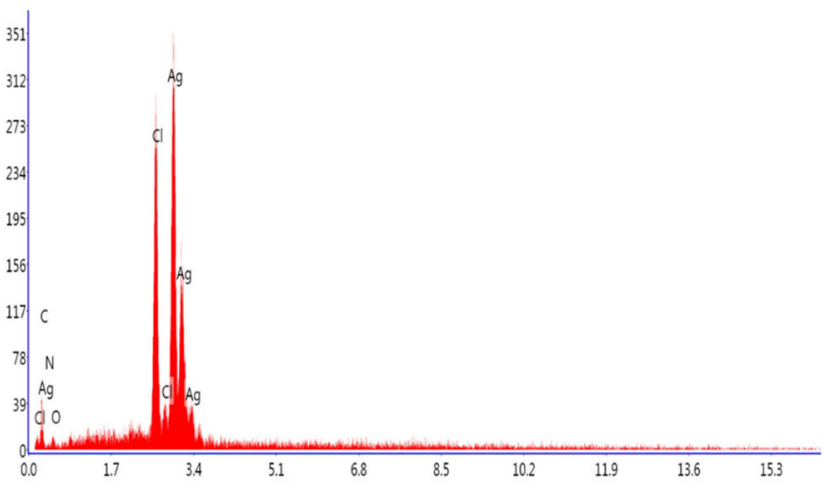

(a) Argemone mexicana AgNPs

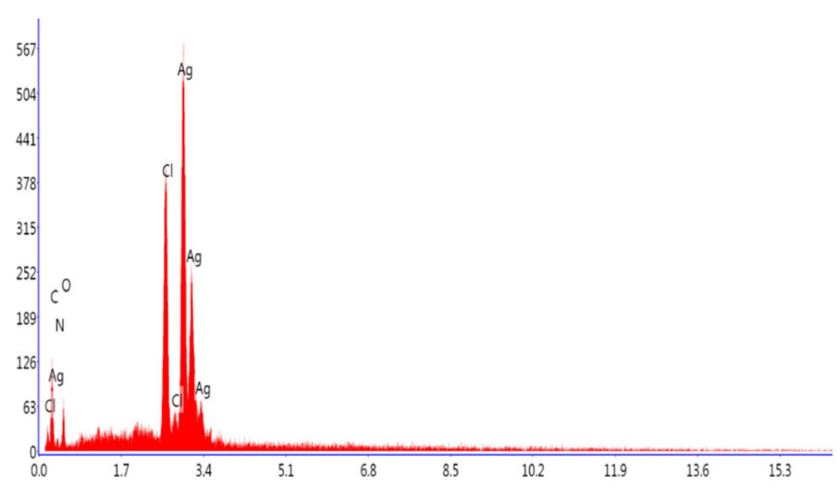

(b) Turnera ulmifolia AgNPs

Fig. 10 EDX spectra for the AgNPs synthesized using blooms concentrate. a Argemone mexicana AgNPs, b Turnera ulmifolia AgNPs

Fig. 11 Antibacterial activity of AgNPs synthesized by blooms concentrate of Argemone mexicana. a Argemone mexicana AgNPs

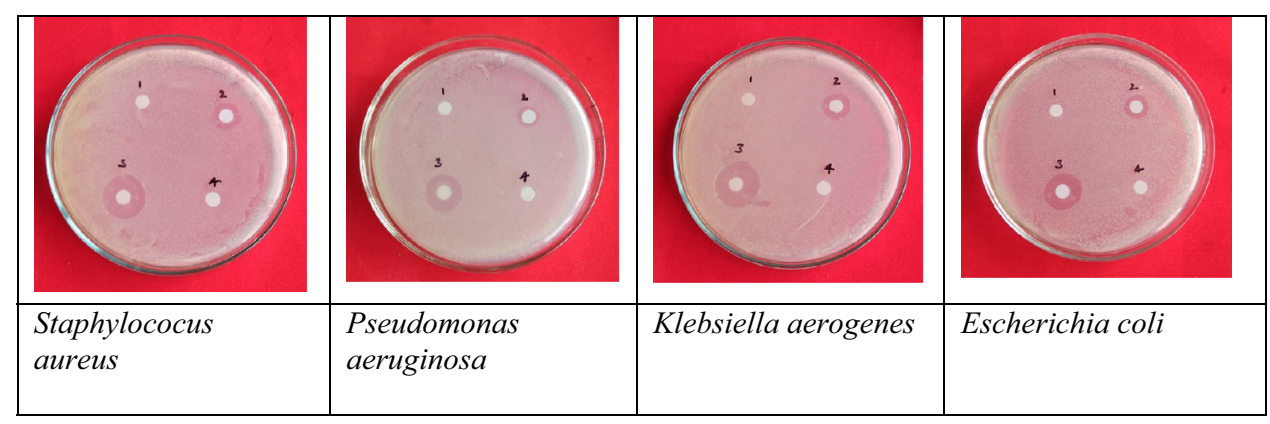

Table 2 Antibacterial zone of inhibition (Argemone mexicana AgNPs)

\begin{tabular}{llllll}
\hline \multicolumn{2}{l}{ Zone of inhibition (in mm) } & & & \\
\hline S. No & Strains & (1) Control & (2) Standard & (3) AgNPs & (4) Blooms Extract \\
\hline 1 & Staphylococus aureus & - & 13 & 23 & - \\
2 & Pseudomonas aeruginosa & - & 8 & 20 & - \\
3 & Klebsiellaaerogenes & - & 13 & 24 & - \\
4 & Escherichia coli & - & 12 & 21 & - \\
\hline
\end{tabular}

Control double distilled water; AgNPs Silver Nanoparticles, Standard Taxim; Blooms Extract Argemone mexicana blooms concentrate

\section{Antioxidant activity}

DPPH assay The synthesized AgNPs exhibited a maximum DPPH scavenging activity of $87.06 \%$ at $500 \mu \mathrm{g} \mathrm{ml}^{-1}$ concentration, whereas for ascorbic acid (standard) was found to be $96.83 \%$ (Table 4 and Fig. 13).

The synthesized AgNPs exhibited a maximum DPPH scavenging activity of $84.62 \%$ at $500 \mu \mathrm{g} \mathrm{ml}^{-1}$, whereas for ascorbic acid (standard) was found to be $94.89 \%$ (Table 5 and Fig. 14).

Reducing power assay The synthesized AgNPs have good reducing power when compared with the reducing power of standard ascorbic acid. The results obtained for the reducing power assay and the bar diagram representation were presented for AgNPs synthesized from A. Mexicana (Table 6 and Fig. 15) and for AgNPs synthesized from T. ulmifolia (Table 7 and Fig. 16).

\section{Conclusion}

The green synthesis of AgNPs has been successfully carried out using the blooms concentrate of A. mexicana and T. ulmifolia. From XRD studies, the average size of produced AgNPs is established to be $29.13 \mathrm{~nm}$ for A. mexicana AgNPs and $31.47 \mathrm{~nm}$ for T. ulmifolia AgNPs, which is close to the size of particles obtained from SEM analysis, i.e., $29.34 \mathrm{~nm}$ for A. mexicana AgNPs and $32.42 \mathrm{~nm}$ for $T$. ulmifolia AgNPs. In FTIR spectra has shown the presence 
Fig. 12 Antibacterial activity of AgNPs synthesized by blooms concentrate of Turnera ulmifolia. b Turnera ulmifolia AgNPs

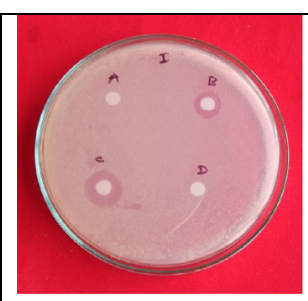

Staphylococus aureus

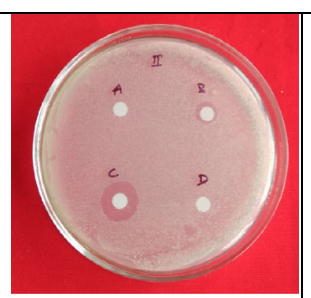

Pseudomonas aeruginosa

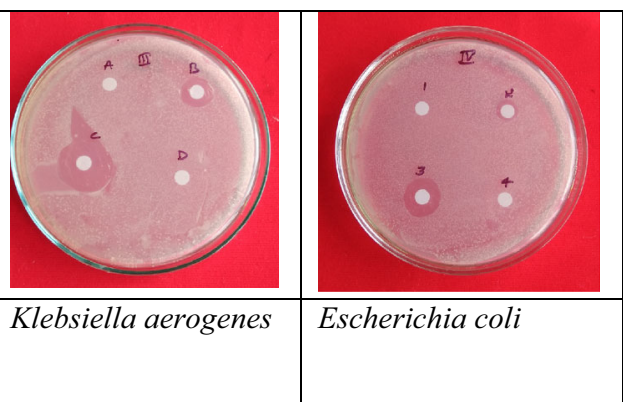

Table 3 Antibacterial zone of inhibition (Turnera ulmifolia AgNPs)

\begin{tabular}{llllll}
\hline \multicolumn{2}{l}{ Zone of inhibition (in mm) } & & & \\
\hline S. No & Strains & (A) Control & (B) Standard & (C) AgNPs & (D) Blooms extract \\
\hline 1 & Staphylococus aureus & - & 12 & 21 & - \\
2 & Pseudomonas aeruginosa & - & 7 & 21 & - \\
3 & Klebsiellaaerogenes & - & 14 & 27 & - \\
4 & Escherichia coli & - & 7 & 21 & - \\
\hline
\end{tabular}

Control double distilled water; AgNPs silver nanoparticles; Standard Taxim, Blooms Extract Turnera ulmifolia blooms concentrate

Table 4 DPPH scavenging activity of AgNPs synthesized by Argemone mexicana blooms concentrate and ascorbic acid

\begin{tabular}{lll}
\hline Concentration of synthesized & \multicolumn{2}{l}{ Scavenging $(\%)$} \\
\cline { 2 - 3 } AgNPs and ascorbic acid $(\mu \mathrm{l})$ & $\begin{array}{l}\text { Synthesized } \\
\text { AgNPs }\end{array}$ & Ascorbic acid \\
\hline 100 & $74.683 \pm 0.053$ & $93.173 \pm 0.052$ \\
200 & $76.021 \pm 0.047$ & $93.841 \pm 0.059$ \\
300 & $78.234 \pm 0.033$ & $95.562 \pm 0.065$ \\
400 & $78.157 \pm 0.056$ & $96.527 \pm 0.073$ \\
500 & $87.063 \pm 0.031$ & $96.836 \pm 0.045$ \\
\hline
\end{tabular}

Values are mean \pm standard deviation of triplicate analyses. Results of each concentration of AgNPs were analyzed separately

of phytocompounds which are responsible for the bioreduction of silver ions into silver nanoparticles. The phytochemical screening of A. mexicana and T. ulmifolia blooms concentrate has shown the presence of flavonoids, saponins, alkaloids, amino acids, phenols, tannins, terpenoids and cardiac glycosides. Green synthesis route is of low cost, non-toxic, vitality (energy) productive, surroundings prompting lesser waste and quicker than the conventional method of synthesizing the AgNPs. AgNPs synthesized from the blooms concentrate of A. mexicana and T. ulmifolia have shown efficient antimicrobial activ-

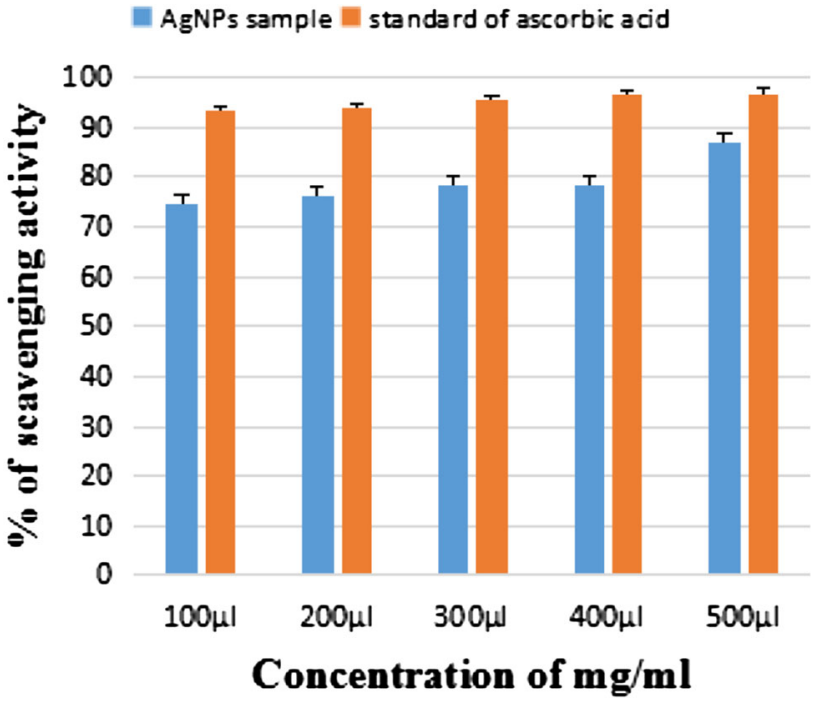

Fig. 13 DPPH scavenging activity of AgNPs synthesized by Argemone mexicana blooms concentrate and ascorbic acid

ities against $E$. coli, $K$. aerogenes, $P$. aeruginosa and $S$. aureus. In vitro antioxidant method by DPPH and reducing power assay has shown that AgNPs synthesized by the blooms concentrate of A. mexicana have better activity than the AgNPs synthesized by the blooms concentrate of T. ulmifolia. In conclusion, biosynthesis of AgNPs using 
Table 5 DPPH scavenging activity of AgNPs synthesized by Turnera ulmifolia blooms concentrate and ascorbic acid

\begin{tabular}{lll}
\hline Concentration of synthesized & \multicolumn{2}{l}{ Scavenging $(\%)$} \\
\cline { 2 - 3 } AgNPs and ascorbic acid $(\mu \mathrm{l})$ & $\begin{array}{l}\text { Synthesized } \\
\text { AgNPs }\end{array}$ & Ascorbic acid \\
\hline 100 & $73.023 \pm 0.064$ & $91.037 \pm 0.025$ \\
200 & $74.521 \pm 0.058$ & $91.148 \pm 0.095$ \\
300 & $76.554 \pm 0.043$ & $93.256 \pm 0.056$ \\
400 & $76.157 \pm 0.067$ & $94.572 \pm 0.038$ \\
500 & $84.620 \pm 0.042$ & $94.896 \pm 0.057$
\end{tabular}

Values are mean \pm standard deviation of triplicate analyses. Results of each concentration of AgNPs were analyzed separately

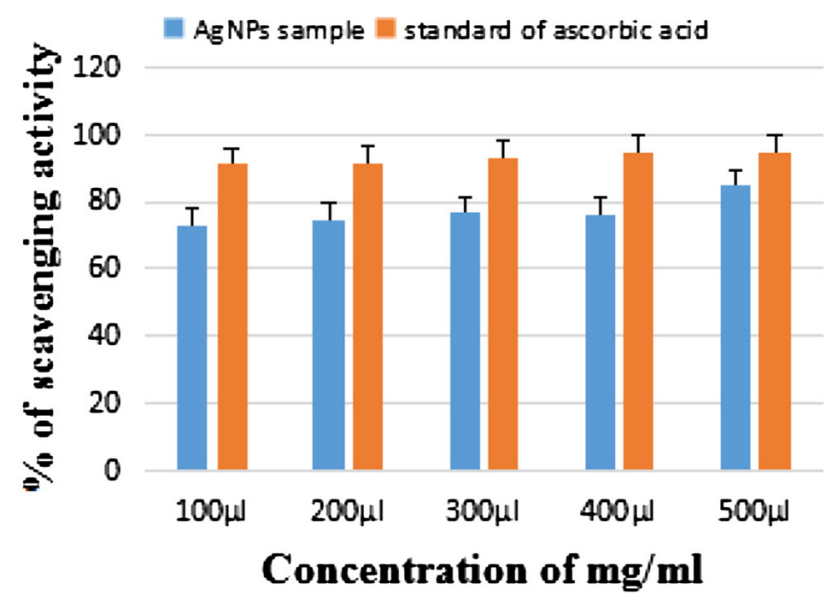

Fig. 14 DPPH scavenging activity of AgNPs synthesized by Turnera ulmifolia blooms extracts and ascorbic acid

Table 6 Reducing power assay of AgNPs synthesized by Argemone mexicana blooms concentrate and ascorbic acid

\begin{tabular}{lll}
\hline \multirow{2}{*}{$\begin{array}{l}\text { Concentration of synthesized AgNPs } \\
\text { and ascorbic acid }(\mu \mathrm{l})\end{array}$} & \multicolumn{2}{l}{ Reducing power $(\%)$} \\
\cline { 2 - 3 } & \multicolumn{1}{l}{$\begin{array}{l}\text { Synthesized } \\
\text { AgNPs }\end{array}$} & $\begin{array}{l}\text { Ascorbic acid } \\
(\text { Std })\end{array}$ \\
\hline 100 & $20.46 \pm 0.041$ & $28.17 \pm 0.055$ \\
200 & $39.59 \pm 0.085$ & $56.96 \pm 0.065$ \\
300 & $60.23 \pm 0.013$ & $72.03 \pm 0.016$ \\
400 & $71.86 \pm 0.047$ & $83.98 \pm 0.058$ \\
500 & $85.9 \pm 0.082$ & $96.89 \pm 0.067$
\end{tabular}

Values are mean \pm standard deviation of triplicate analyses. Results of each concentration of AgNPs were analyzed separately

plant material is an easy, ecologically friendly and conventional method compared to the chemical and physical methods of synthesis. This method is significantly used because the plants are widely distributed in nature, safe to

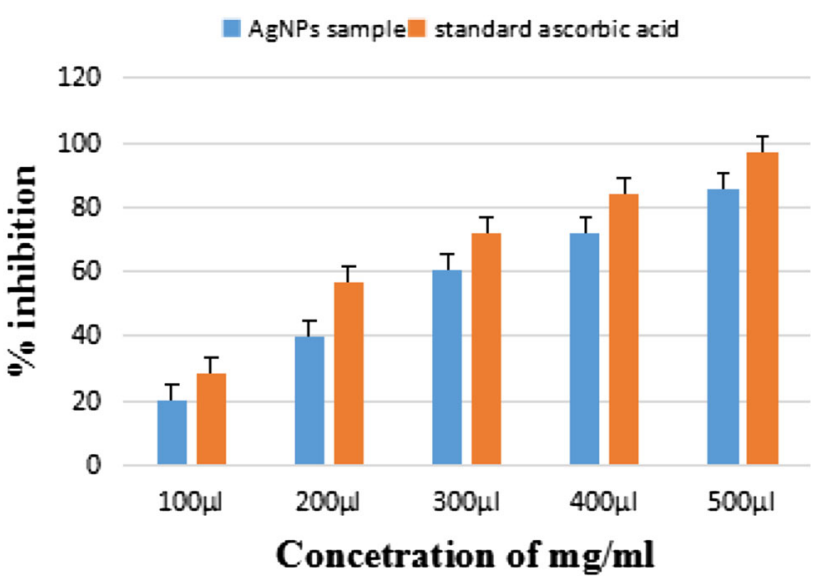

Fig. 15 Antioxidant activity by reducing power assay of Ascorbic acid and AgNPs synthesized from Argemone mexicana blooms extracts. Turnera ulmifolia

Table 7 Reducing power assay of AgNPs synthesized by blooms concentrate and ascorbic acid

\begin{tabular}{|c|c|c|}
\hline \multirow{2}{*}{$\begin{array}{l}\text { Concentration of synthesized AgNPs } \\
\text { and ascorbic acid }(\mu \mathrm{l})\end{array}$} & \multicolumn{2}{|l|}{ Inhibition (\%) } \\
\hline & $\begin{array}{l}\text { Synthesized } \\
\text { AgNPs }\end{array}$ & Ascorbic acid \\
\hline 100 & $17.66 \pm 0.054$ & $25.71 \pm 0.055$ \\
\hline 200 & $36.95 \pm 0.048$ & $53.96 \pm 0.045$ \\
\hline 300 & $57.23 \pm 0.063$ & $69.3 \pm 0.016$ \\
\hline 400 & $67.86 \pm 0.027$ & $80.98 \pm 0.088$ \\
\hline 500 & $81.19 \pm 0.052$ & $93.18 \pm 0.067$ \\
\hline
\end{tabular}

Values are mean \pm standard deviation of triplicate analyses. Results of each concentration of AgNPs were analyzed separately

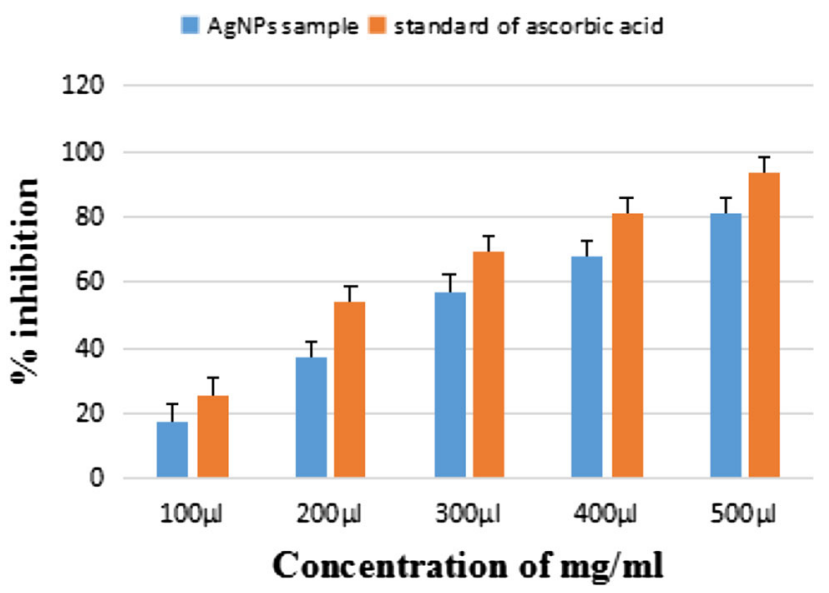

Fig. 16 Antioxidant activity by reducing power assay of Ascorbic acid and AgNPs synthesized from Turnera ulmifolia blooms concentrate

handle, nontoxic, easily available and low cost. Further studies are needed to optimize the scaling up of the synthesis of silver nanoparticles.

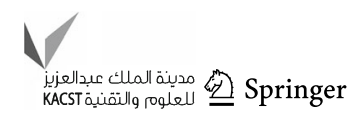


Acknowledgements We thank Dr. M R Hulinaykar, Managing Trustee, Sri Shridevi Charitable Trust, Dr. H. B. Phani Raju, Principal, Shridevi Institute of Engineering and Technology, Tumakuru, India for their encouragement during the research work. We thank the staff, Department of material science, BMSCE, Bangalore, Karnataka, India, for their service in assisting with SEM analysis facility during this research work. We thank the staff, Department of Chemistry, Government Arts and Science College, Bangalore, Karnataka, India, for their help in assisting with FTIR analysis facility during this research work. We thank the staff, Department of microbiology, Shridevi Institute of Medical Sciences and Research Hospital, Tumakuru, Karnataka, India for providing bacterial strains.

\section{Compliance with ethical standards}

\section{Conflict of interest None.}

Open Access This article is distributed under the terms of the Creative Commons Attribution 4.0 International License (http:// creativecommons.org/licenses/by/4.0/), which permits unrestricted use, distribution, and reproduction in any medium, provided you give appropriate credit to the original author(s) and the source, provide a link to the Creative Commons license, and indicate if changes were made.

\section{References}

Abdelghany TM, Al-Rajhi AMH, Al Abboud MA (2017) Recent advances in green synthesis of silver nanoparticles and their applications: about future directions. A review. BioNanoScience. doi:10.1007/s12668-017-0413-3

Agrawal PN, Kulkarni NS (2017) Biosynthesis and characterization of Silver nanoparticles. Int J Curr Microbiol Appl Sci 6(4):938-947

Arora Rashmi, Grewal Anita (2015) Biogenic synthesis, characterization of silver nanoparticles from Candelula officinalis extract and evaluation of their antimicrobial activity. Nano Biomed Eng $7(2): 47-51$

BSBI List (2007) Botanical Society of Britain and Ireland. Archived from the original (xls) on 201501 25. Retrieved 17 Oct 2017

Chandrappa CP, Anitha R, Jyothi P, Rajalakshmi K, Seema Mahammadi H, Govindappa M, Sharanappa (2013) Phytochemical analysis and antibacterial activity of endophytes of Embelia tsjeriam cottam Linn. Res Artic Biol Sci 3(1):467-473

Chen X, Schluesener HJ (2008) Nanosilver: a nanoproduct in medical application. Toxicol Lett 176(1):1-12

Chen J, Ouyang J, Kong J, Zhong W, Xing MM (2013) Photo-crosslinked and $\mathrm{pH}$-sensitive biodegradable micelles for doxorubicin delivery. ACS Appl Mater Interfaces 5(8):3108-3117

Coutinho HD, Costa JG, Lima EO, Falcão-Silva VS, Júnior JP (2009) Herbal therapy associated with antibiotic therapy: potentiation of the antibiotic activity against methicillin-resistant Staphylococcus aureus by Turnera ulmifolia. BMC Complement Alt Med 9(1):13

Daizy P (2011) Spectrochim Acta, Part A 78:327-331

Dimitrijevic NM, Bartels DM, Jonah CD, Takahashi K, Rajh T (2001) Radiolytically induced formation and optical absorption spectra of colloidal silver nanoparticles in supercritical ethane. J Phys Chem B 105:954-959

Borrell B (2014) Drug developers take a second look at herbal medicines. Scientific American, vol 310(6), pp 64-69, June 2014

El-Badawy A, Feldhake D, Venkatapathy R (2010) State of the science literature review: everything nanosilver and more. US Environmental Protection Agency, Washington DC
Galiano K, Pleifer C, Engelhardt K et al (2008) Silver segregation and bacterial growth of intraventricular catheters impregnated with silver nanoparticles in cerebrospinal fluid drainages. Neurol Res 30(3):285-287

Kalishwaralal K, Deepak V, Ram Kumar Pandian S, Kottaisamy M, BarathmaniKanth S, Kartikeyan B et al (2010) Biosynthesis of silver and gold nanoparticles using Brevibacterium casei. Colloids Surf B Biointerfaces 77:257-262

Karthika P, Dheeba B, Sivakumar R, Sheik Abdulla S (2014) Plant mediated synthesis and characterization of silver nanoparticles. Int J Pharm Pharm Sci 6(8):304-310

Karuppiah M, Rajmohan R (2013) Green synthesis of silver nanoparticles using Ixora coccinea leaves extract. Mater Lett 97:141-143

Mohamed A, Xing MM (2012) Nanomaterials and nanotechnology for skin tissue engineering. Int J Burns Trauma 2(1):29-41

Moore M (1990) Los Remedios: traditional herbal remedies of the Southwest. Museum of New Mexico Press, Santa Fe

Moore K (2006) A new silver dressing for wounds with delayed healing. Wounds UK 2(2):70-78

Murali Krishna G, Bhagavanth Reddy G, Veerabhadram A Madhusudhan (2016) Eco-friendly green synthesis of silver nanoparticles using salmalia malabarica: synthesis, characterization, antimicrobial, and catalytic activity studies. Appl Nanosci 6:681-689

Naik RR, Stringer SJ, Agarwal G, Jones SE, Stone MO (2002) Biomimetic synthesis and patterning of silver nanoparticles. Nat Mater 1:169-172

Pandey S, Oza G, Mewada A, Sharon M (2012) Green synthesis of highly stable gold nanoparticles using, Momordica charantia as nano fabricator. Arch Appl Sci Res 4:1135-1141

Patel RM, Patel NJ (2010) In vitro antioxidant activity of coumarin compounds by DPPH, Super oxide and nitric oxide free radical scavenging methods. J Adv Pharm Educ Res 1:52-68

Sastry M, Ahmad A, Khan MI, Kumar R (2003a) Microbial nanoparticle production in Nanobiotechnology. NanoBiotechnology 85:163-169

Sastry M, Ahmad A, Islam NI, Kumar R (2003b) Biosynthesis of metal nanoparticles using fungi and actinomycetes. Current Sci $85: 162-170$

Sathyavathi R, Krishna MB, Rao SV, Saritha R, Rao DN (2010) Biosynthesis of silver nanoparticles using coriandrum sativum leaf extract and their application in nonleniar optics. Adv Sci Lett 3:1-6

Sibbald RG, Contreras-Ruiz J, Coutts P, Fierheller M, Rothman A, Woo K (2007) Bacteriology, inflammation, and healing: a study of nanocrystalline silver dressings in chronic venous leg ulcers. Adv Skin Wound Care 20(10):549-558

Siddiqui AA, Ali M (1997) Practical pharmaceutical chemistry, 1st edn. CBS Publishers and Distributors, New Delhi, pp 126-131

Skirtach AG, Muñoz Javier A, Kreft O et al (2006) Laser-induced release of encapsulated materials inside living cells. Angew Chem Int Ed Engl 45(28):4612-4617

Sofowora A (1993) Medicinal plants and traditional medicine in Africa. Spectrum Books, Ibadan, p 150

Sun Y, Yin Y, Mayers BT, Herricks T, Xia Y (2002) Uniform form silver nanowires synthesis by reducing $\mathrm{AgNO} 3$ with ethylene glycol in presence of seeds and and poly(vinyl pyrrolidone). Chem Mater 14:4736-4745

Tian Y, Chen J, Zahtabi F, Keijzer R, Xing M (2013) Nanomedicine as an innovative therapeutic strategy for pediatric lung diseases. Pediatric Pulmonol 48(11):1098-1111

Trease GE, Evans WC (1989) Pharmacognosy, 13th edn. Bailliere Tindall, London, pp 176-180

Uchihara T (2007) Silver diagnosis in neuropathology: principles, practice and revised interpretation. Acta Neuropathol 113(5):483-499 
Ugochukwu SC, Arukwe Uche I, Ifeanyi O (2013) Preliminary phytochemical screening of different solvent extracts of stem bark and roots of Dennetia tripetala G. Baker Pelagia Res Libr 3(3):10-13

Vigneshwaran N, Kathe AA, Varadarajan PV, Nachane RP, Balasubramanya RH (2007) Functional finishing of cotton fabrics using silver nanoparticles. J Nanosci Nanotechnol 7(6): 1893-1897

Wagner H, Blodt (1996) Plant drug analysis: a thin layer chromatography atlas, 2nd edn. Springer-Verlag, Berlin Heidelberg

Willco ML, Graz B, Falquet J, Diakite C, Giani S, Diallo D (2011) A reverse pharmacology approach for developing an anti-malarial phytomedicine. Malar J 10(1):8
Xing M, Zhong W, Xu X, Thomson D (2010) Adhesion force studies of nanofibers and nanoparticles. Langmuir 26(14):11809-11814

Yin B, Ma H, Wang S, Chen S (2003) Electrochemical synthesis of silver nanoparticles under protection of poly ( $\mathrm{N}$-vinylpyrrolidone). J Phys Chem B 107:8898-8904

Zhong W, Xing MM, Maibach HI (2010) Nanofibrous materials for wound care. Cutan Ocul Toxicol 29(3):143-152

\section{Publisher's Note}

Springer Nature remains neutral with regard to jurisdictional claims in published maps and institutional affiliations. 